\section{For og om pasienter med thyreoideasykdom}

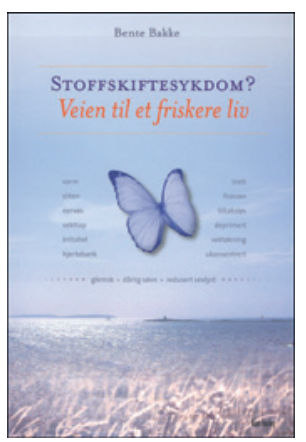

Bente Bakke

\section{Stoffskiftesykdom?}

Veien til et friskere liv. $288 \mathrm{~s}$.

Oslo: Kom forlag, 2011. Pris NOK 249

ISBN 978-82-92496-99-2

Boken er skrevet fra pasientens ståsted og inneholder 20 kapitler med mange underkapitler. Forfatteren omtaler de fleste sykdomstilstandene av thyreoidea, med mest vekt på klassisk hypo- og hypertyreose. Dette belyses med egne erfaringer, andre pasienters erfaringer og med flere helsearbeideres meninger om de ulike tilstandene.

Det er ingen illustrasjoner. Videre er det heller ikke direkte referanser til en del utsagn i teksten, og dette kan skape noe usikkerhet om hvor opplysningene/påstandene i teksten er hentet fra. Andre steder siteres navngitte personer eller litteratur.

Forfatteren understreker både i forordet og i faktainformasjon at dette ikke er en medisinsk fagbok. Likevel vil nok mange pasienter oppfatte mye av det som står der som «sant», selv om mange av behandlingsforslagene, kostveiledningen etc. er omdiskutert.

Uansett vil mange pasienter få nyttig informasjon om de ulike stoffskiftesykdommene. Det kommer også klart frem at det kan være store individuelle variasjoner i symptomene, fra svært lite plager med store laboratoriemessige forstyrrelser (dette står det lite om i boken), til mye plager - men små laboratoriemessige avvik. Forfatteren beskriver også at responsen på behandlingen kan være svært individuell, kanskje spesielt for pasienter med hypotyreose. Dette er etter hvert godt kjent.

$\mathrm{Vi}$ tror nå at den tidligere underdiagnostiseringen som beskrives i teksten, av både lavt og høyt stoffskifte, med stor sannsynlighet er liten. Noen av de vanligste blodprøvene som i dag tas hos pasienter med ulike plager, er TSH og FT4, for nettopp å utelukke thyreoideasykdom. Patologiske prøvesvar fører til oppfølging av pasientene. Pasienter med hypertyreose som ofte krever spesiell oppfølging, blir i stor grad behandlet på spesialistpoliklinikkene, mens behandling av hypotyreose primært er en fastlegeoppgave. Dette skyldes dels manglende kapasitet på spesialistpoliklinikkene, men også at denne tilstanden medisinsk sett er «enklere» å behandle.

Grensene for når behandling av subklinisk hypotyreose (riktigere kalt latent hypotyreose, siden en del av pasientene har symptomer) skal starte, er omdiskutert. I denne teksten synes man å ha lagt seg svært langt mot å behandle også de med marginale laboratoriemessige endringer.

Dette er primært en bok for erfaringsutveksling mellom personer med stoffskiftesykdom og deres pårørende. Men det er alltid nyttig også for helsepersonell å lese slik litteratur. Et godt norsk fagbokalternativ for leger vil være Aanderud og Bjøros Thyreoideasykdommer (1).

\section{Per Medbøe Thorsby}

Hormonlaboratoriet

Oslo universitetssykehus

\section{Litteratur}

1. Aanderud S, Bjøro T, red. Thyreoideasykdommer: årsaker, diagnostikk og behandling. 2. utg. Oslo: Gyldendal akademisk, 2002

\section{Verdifullt om medikamenter og pasienter}

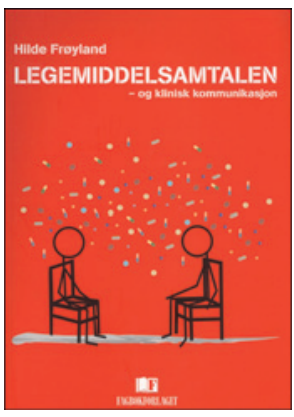

\author{
Hilde Frøyland \\ Legemiddelsamtalen -
}

og klinisk kommunikasjon

202 s, ill. Oslo: Fagbokforlaget, 2011.

Pris NOK 279

ISBN 978-82-450-1061-9

Tittelen peker mot et svært avgrenset område, nemlig legemiddelsamtalen. Legemiddelsamtalen er nærmere definert, med henvisning til Helsedirektoratet, som en systematisk gjennomgang av pasientens legemiddelbruk. Hensikten er at legemiddelbrukeren får innsikt i, blir trygg på og oppnår best mulig effekt av sin legemiddelbehandling. Uten at det legges noen klar føring for bruk av tid, nevnes 30-45 minutter som tilstrekkelig i de fleste tilfellene.

Det nevnes at andre faggrupper, inkludert leger, kan gjennomføre slike samtaler, men man får inntrykk av at målgruppen stort sett er farmasøyter. Og det er synd, for her er mangt å hente for enhver som både håndterer medikamenter og pasienter. Boken er full av gode eksempler på informasjonsutveksling, hvor komplekst det er, og hvor fort gjort det er å bidra til misforståelser. Forfatteren viser også hvor nødvendig det er å sette av tid til informasjon om legemidler, altfor ofte forskriver vi uten å bruke tilstrekkelig tid til å gjennomgå hva forskrivningen innebærer.

Fordi forfatteren går grundig til verks, gjennom innledende omtale av begrepsbruk og definisjoner, via 20 sider om språk, nye 20 sider om sykdom og sykdomsforståelse, og ti sider om anerkjennelse og autonomi før hun endelig kommer til kjernen, vil mange potensielle lesere kanskje vende seg vekk. Men da vil jeg ile til og hevde at jeg ikke kan huske å ha lest en mer presis og kortfattet gjennomgang av vesentlige filosofiske og empiriske tilnærminger til forståelsen av hva som foregår mellom en pasient og en hjelper. Forfatteren er dessuten ytterst språkbevisst, klar og lettlest - noe som forsterker inntrykket av et gjennomarbeidet stoff. Hyggelig er det å konstatere at samtalerådene hun gir, er helt på linje med det som vi underviser i dag når det gjelder lege-pasient-kommunikasjon generelt. Og det står ikke til å nekte at jeg kjente et stikk av dårlig samvittighet $\mathrm{i}$ forhold til egen atferd ved forskrivning etter hvert som eksempelrekken bygde seg opp.

Når det er sagt, beskriver forfatteren et ideal som vil være vanskelig å følge opp i daglig praksis. Av alle kommunikasjonsferdigheter er nok den å gi informasjon den som tar lengst tid, og i hverdagen må leger ofte prioritere og sette av mest tid til dem som trenger flere medikamenter, eller til dem som begynner å trekke på årene. Rådgivningen er likevel så konkret at enhver vil finne noe å bruke.

Pål Gulbrandsen

Institutt for klinisk medisin

Universitetet i Oslo 